\title{
Preliminary Research on the Construction of Education Quality Assurance System of the Open Universities
}

\author{
Yan ZHANG \& Ming LI \\ Institute of Higher Education, Beijing University of Aeronautics and Astronautics, Beijing, 100191, China
}

Qian SHAN

Institute of Technology, Beijing Open University, Beijing, 100081, China

\begin{abstract}
The open universities are new things in the process of China's higher education development. Its development depends on the quality. The construction of education quality assurance system is both the bottleneck of modern distance education development and the challenge facing the development of the open universities. The development of modern distance education has distinctive stage characteristics, with government-led quality management features and deep quality assurance bottleneck. Guaranteeing and improving the education quality of the open universities needs to resort to the scientific and rational view of the education quality and to improve the external evaluation mechanism of combining the government, thirdparty organization and society as well as the internal teaching quality assurance system.
\end{abstract}

KEYWORD: Open University; education quality assurance system; modern distance education; assessment

\section{INTRODUCTION}

As a major education innovation mechanism adapting to the social development, the open universities have an important practical and longterm strategic significance for the overall development of China's higher education. In recent years, the discussion on "scale" and "quality" of distance education continues to heat up, and has attracted wide attention. Along with the start of the open education pilot project by MOE (Ministry of Education of the People's Republic of China), the theoretical research on "open distance education quality assurance system" also appeared. From the perspective of the specific research, the construction of open distance education quality assurance system is most scholars' research priorities and becomes diversified; in terms of the final outcome of the research, although the research on open distance education quality assurance has yielded some progress, the depth is not enough, and there are some one-sided errors [1]. Guaranteeing and improving the education quality of the open universities involves the government and the public's accountability and recognition for the level of running the open universities as well as the future survival and development of the open universities. By identifying the education quality problems of open universities, we can put forward the targeted substantive strategies for the construction of education quality assurance system of open universities.

\section{REVIEW OF DISTANCE EDUCATION DEVELOPMENT HISTORY FROM THE PERSPECTIVE OF QUALITY ASSURANCE}

Distance higher education went through three development stages [2]: the preparation stage of distance higher education (1994-1998); the construction stage of distance higher education (1999-2000); the reorganization stage of distance higher education (since 2001).

\subsection{Quality Assurance: Core Issues of Distance Education Development}

From the perspective of the development of modern distance higher education, the quality management has been the focus of the government monitoring and management. The government attaches great importance to the development of distance higher education since its inception. The Chinese government plays an important role in "organizing, planning, coordinating and monitoring" the development of distance higher education and has always stressed quality assurance. In the early stage of modern distance education, China had planned to carry out the evaluation of the educational quality. MOE also requires pilot universities to carry out the 
annual report and inspection every year. In addition, the government performs its monitoring and management functions through the establishment of the Central Radio \& TV University system and the implementation quality of modern distance education project. In recent years, in order to enhance the quality of distance higher education, the State established the off-campus study service system (such as the establishment of digital learning harbour and demonstration learning centre, etc.). Based on a series of quality assurance activities, China has established an organization system with certain quality assurance functions in the field of distance education quality assurance. However, because the quality assurance system of distance education is not perfect yet, the recognition of quality and management mechanism still needs to improve [3].

\subsection{Quality Anomie: the Bottleneck Restricting Distance Education Development}

Compared with ordinary universities, the implementation of open education in the Central Radio \& TV University and the ordinary university network institute enjoys more school-running autonomy. Although the government gave school runners more autonomous rights, it did not conduct scientific norms and proper guidance according to the market rule, so that the external promotion system of China's open distance education quality has the problems such as "lack of the external promotion system of education quality matching market-oriented school-running and failure of the traditional education quality promotion system" [4], which ultimately led to that the core issue-the quality of education was likely to be ignored and had the danger of being marginalized in the context that marketization had an impact on higher education. In addition, the government-led centralization security system lacks monitoring mechanisms and transparency, quality assurance system is not perfect, and quality assurance lacks reutilization, resulting in the absence of "the inherent self-restraint mechanism of teaching quality. [5]" An important manifestation of the absence of the inherent self-restraint mechanism is to ignore the dominant position of "learners". As the most important stakeholders of open distance education, learners' interests and willingness to participate in the school quality management and supervision should be met. Learners' participation in school quality supervision could not be just a mere formality or just stay at the conceptual level. Learners should directly involve in the quality assurance system and form part of the quality assurance [6].
3 CONSTRUCTION OF EDUCATION QUALITY ASSURANCE SYSTEM DETERMINES THE SUCCESS OR FAILURE OF FUTURE DEVELOPMENT OF THE OPEN UNIVERSITIES

\subsection{Significance of Construction of Quality Assurance System}

The open universities are importantly innovative form of higher education, and have all the factors of higher education teaching. Quality assurance in education is a node of the entire closed teaching loop, and cannot be lacked. Quality assurance in teaching, together with diverse means of control and supervision, quality assurance strategy and related factors, constitutes the unified whole of the open universities [7]. Quality assurance system is composed of internal quality assurance and external quality assurance. According to the system theory, "the system, as a whole, has some new characteristics which do not exist in its constituents." As a complex system, the construction of education quality assurance system of the open universities should take into account both internal and external systems, either of which cannot be neglected. Distance education factors determine that teachers and students are in the state of spatial and temporal separation. The professionalism and learning habits of each learner are quite different, so the education quality assurance of the open universities has the characteristics of multilevel, multi-agency, multi-interference and distortion [8].

\subsection{Current Situation of Education Quality Assurance of the Open Universities}

At present, although China has initially established a quality assurance system of higher education, the quality assurance system construction of open distance education has "deficiencies". The main problems are as follows [9]: quality assurance subject and the evaluation subject are single, there is a lack of professional evaluation institutions and personnel, and social group participation is not high; evaluation tools and methods are not scientific; the quality environment is not standardized, and quality culture construction is ignored; the contradiction between the vigorous development of the quality assurance activities and the lagged construction of related laws and regulations is increasingly prominent. Among these problems, the most pressing one is undoubtedly the absence of education quality monitoring system. Higher education quality monitoring system puts too much emphasis on the central government's dominance, and lacks the effective social evaluation and evaluation of the third party organization as well as appropriate quality control standards. In addition, "the education quality monitoring system within the schools is not perfect, 
and Teaching evaluation is still in the stage of summative evaluation model" [10]. Shift from pure pursuit of the size and number to the creation of content and quality improvement objectively requires the open universities to consciously cultivate the appropriate macro and micro management system and mechanism. Only by continuing to improve and strengthen the internal and external education quality control and assurance system, the sound education system of the open universities with quality improvement as the core can be established in the reform and development.

\section{REFLECTION ON THE CONSTRUCTION OF EDUCATION QUALITY ASSURANCE SYSTEM OF THE OPEN UNIVERSITIES}

\subsection{Reasonable position}

The open universities are the product of the in-depth integration of education and technology. Its uniqueness requires us to comprehensively evaluate its quality with the overall view. "Different levels of students, curriculum orientation and evaluation criteria would restrict the quality construction of the open universities. [11]" Outline of National Medium and Long-term Education Reform and Development Planning (2010-2020) (hereinafter referred to as the Outline) made it clear that it is necessary to establish the scientific concept of quality, and take promoting the comprehensive development of the people and meeting the social needs as a fundamental standard of measuring education quality. The open universities shall uphold the "student-centred" philosophy, and let them participate in the whole process of course goal setting and teaching quality assessment, which not only can enhance students' learning satisfaction but also improve the education quality assurance. More importantly, with the changing times, new ideas and technologies will affect people's opinions about the education quality and attitude adjustment. We should evaluate the quality of the open universities from the developmental perspective and let a wide range of constituencies to participate in the quality assurance system of the open universities to make them "keep pace with the times", which is the connotation of the quality concept of the open universities under the background of popularization of higher education and learning society construction.

\subsection{Improve the Diverse External Evaluation Mechanism and Ensure the Education Quality of the Open Universities}

External quality assurance is designed to improve the allocation of education activity resources and promote the connotative development of universities, so as to meet the basic quality standards and promote a virtuous circle among schools, government and the community. In the face of the concerns and questions from government, the academic community and market forces, etc., the universities shall respond publicly to the education quality to be complementary to the external quality assurance measures such as accountability, accreditation and assessment [12]. Therefore, when establishing education quality assurance system of the open universities, we should also pay attention to the construction of external quality monitoring system. Specifically, the external evaluation of the open universities should include "the government assessment, accreditation and social evaluation [13]." Firstly, we shall reasonably play the role of government assessment in the external quality control. It is necessary to redefine the scope of the powers and responsibilities of government to reasonably play the supervisory and management functions. Secondly, we must strive to establish a third-party accreditation system with international substantive equivalence. According to the international practice, the active assessment of thirdparty organization or application for accreditation of international qualified accreditation organization is an important means to protect the education quality of open universities. Thirdly, we shall pay attention to attract social forces to participate in quality assessment. The open universities are new universities established in China's lifelong learning process with "openness to people, place, method and concept" [14], so that the local economic and social development produced the close ties. The open universities are kind of social universities which should be combined with industry needs to set up certain level and credit-based courses in accordance with job competency requirements [15]. The open universities shall face and adapt to the needs of society; quality evaluation of the open universities should focus on external assessment and social participation, timely reflect the social requirement for talent cultivation, the status of the graduates and the public satisfaction for the demand for lifelong learning diversity, and indirectly regulate education quality. Through government evaluation, third-party accreditation and social assessment, it is necessary to effectively reflect the social demand for talent training, lifelong learning diversity and personalization to the education of the open universities, take the open universities' advantage to really create a learning atmosphere of "everyone is learning, always able to learn, learn everywhere", indirectly monitor the quality education and promote the open universities to continues to develop in the right direction. 


\subsection{Improve the Internal Teaching Quality Assurance System}

University teaching system consists of several subsystems. Among them, teaching subsystem is the foundation and core of education quality assurance. According to the System Theory, the construction of the internal teaching quality assurance system of the open universities should take full account of several important dimensions. Safeguarding the internal teaching quality needs the close coordination and healthy operation between all aspects of the teaching process [16]. It is necessary to adjust quality standards and programs, constantly revise system structure, and optimize design process. Among the above dimensions, the emphasis and difficulty are to construct the teaching quality evaluation system and teaching (course) resource quality evaluation system. To build open universities well, we need build a teaching quality evaluation system that can reflect the teaching process and effect under the background of distance education after establishing a correct concept of distance education and teaching quality [17]. In the case of the dependence on external quality constraints and the lack of effective supervision mechanism, education subject will lack long-term development momentum. The normal operation of the external system needs to be supported by the strict internal quality standards [18]." For the runners of open universities, the focus should be the establishment of an internal quality assurance system. Under the new background, the teaching quality evaluation system of the previous traditional TV universities is difficult to adapt to the new demands of development, and especially cannot meet the needs of the construction of the open universities and future development. The "evaluation subject and mechanism", "teachers' teaching evaluation", "students' learning outcomes evaluation" etc. are still very weak [19]. Construction of internal teaching quality evaluation system should be formulated based on constructivism theory and education evaluation theory, and the appropriate evaluation indicators, procedures and principles should be established by focusing on the abovementioned aspects. In terms of the specific operation and implementation, each school should not be constrained and conservative but build a suitable teaching evaluation system according to its own education situation. In addition, the education quality of open universities also depends on the quality of course system. Highquality education of open universities is inseparable from the high-quality courses. Therefore, all kinds of open universities at all levels shall actively explore the course construction and quality assurance strategy, and actively learn the advanced experience and philosophy from the domestic and international counterparts [20].

\section{CONCLUSION}

The Outline clearly puts forward to "run the open universities well." The open universities are characterized by providing open, flexible, virtual and distributed teaching methods, and are important carriers and ways to build a lifelong learning society ${ }^{[21]}$. The quality assurance system is related to that if China's lifelong learning macro education policy can be successfully implemented, which is the "lifeline" for the development of the open universities.

At the practical level, the open universities at all levels have had some useful exploration in the construction of the internal and external quality assurance system. For example, through the practice of quality assessment work of "International Open Distance Education Association", Shanghai Open University learned, understood and analyzed "University Undergraduate Teaching Assessment Review Program (Trial)"(hereinafter referred to as the "Program") published by the Department of Higher Education, MOE. The "Program" stressed assurance of teachers, teaching resources, teaching reform and teaching quality system as well as the measures taken by the school and the effect [22]. As a new-type university to implement an open and continuing education, the teaching quality is bound to get more and more social attention. Focusing on the education quality assurance and improvement of open universities and building the internal and external integrated education quality assurance system is an inevitable choice to create a good image of open universities, embody school-running characteristics and maintain their long-term development.

To guarantee the teaching quality of open universities, it is necessary to give a scientific and reasonable positioning for education quality concept of open universities, implement the external evaluation mechanism of government evaluation, third-party accreditation and social evaluation, and improve the internal teaching quality assurance system. In 2014, the MOE will promote the undergraduate teaching evaluation, fully respect and develop the subjectivity of the school, and provide space and platform for the connotation development, feature development, innovation development. Confronted with the government, society and public accountability for education, universities necessarily will shift from the pursuit of "quantity" to "quality". All types of open universities shall build a sound scientific teaching quality assurance system and get the sustainable competitiveness with their own characteristics and increasingly high quality on the basis of strengthening the connotation construction. 


\section{ACKNOWLEDGEMENTS}

The research work was supported by "Research on External Quality Assurance of the Open Universities", 2012 topic of National Education Science "Twelfth Five Year Plan" Key topic of Ministry of Education, No.DDA120196.

\section{REFERENCES}

[1] Li Qingqing, Comparative Study in the Chinese and British Open Distance Education Quality Assurance System. Master's degree thesis of Shaanxi Normal University, 2012.

[2] Cheng Huina, Comparative Study in the Chinese and American Distance Higher Education Quality Assurance System. Master's degree thesis of Fujian Normal University, 2011.

[3] Yu Wenbo, Strategy for Quality Assurance System Construction of Open Universities Journal of Liaoning Radio and Television University, 4, pp. 28, 2012.

[4] Jiao Chuanzhen, Reflection and Construction of External Education Quality Promotion System of China's Open Universities education and occupation, 3, pp. 175, 2013.

[5] Chen Bin, History and Thought of Distance Education Quality Assurance China Educational Technology, 3, pp. 58,2011

[6] Gu Fengiia, Reflections on the Open University's Quality Assurance System -From the Perspective of Learner ParticipationOpen Education Research, 17 (6), pp. 49-50, 2011.

[7] Fu Gangshan \& Ma Hongliang, Network Distance Education Beijing Science Press, pp. 247, 2007.

[8] Yu Wenbo, Strategy for Quality Assurance System Construction of Open Universities Journal of Liaoning Radio and Television University, 4, pp. 28, 2012.

[9] Li Qingqing, comparative study in the Chinese and British open distance education quality assurance system. Master's degree thesis of Shaanxi Normal University, 2012.
[10] Sun Hui, Research on Education Quality Monitoring System of China's Network Open Distance University pp. 17-18, 2011.

[11] Zhou Wei \& Wang Xiaowen, Understanding and Thinking of the Connotation of the Open University Quality Evaluation Modern Distance Education, 1, pp. 5354, 2013.

[12] Jia Yuchao \& Liu Yongquan, Accountability-New Development of External Quality Assurance of Western Countries' Distance Higher Education Modern Distance Education, 4, pp. 31-36, 2013.

[13] Sun Hui, Research on Education Quality Monitoring System of China's Network Open Distance University pp. 32, 2011.

[14] Sun Hui, Research on Education Quality Monitoring System of China's Network Open Distance University pp. 29-30, 2011.

[15] Liu Yongquan, Inspiration of Hong Kong Qualifications Framework for External Quality Assurance Construction of Open University. Modern Distance Education, 4, 2013.

[16] Tan Jinsheng \& Liu Peng, Research on Composition of Distance Education Teaching Quality Guarantee System Modern Education, 5-6, pp. 12-14, 2013.

[17] Xiao Zhiming, Study on Open University Teaching Quality Evaluation System Guangxi Education, 5, pp. 79, 2012.

[18] Chen Kaiquan \& Liu Meng, External Evaluation: the Inevitable Path to the Distance Higher Education Quality Assurance. Journal of Distance Education, 5, pp. 33-36, 2008.

[19] Xiao Zhiming, Study on Open University Teaching Quality Evaluation System, Guangxi Education, 5, pp. 79, 2012.

[20] $\mathrm{Yu}$ Wenbo, strategy for quality assurance system construction of open universities Journal of Liaoning Radio and Television University, 2012 (4): 29.

[21] Yu Wenbo, strategy for quality assurance system construction of open universities Journal of Liaoning Radio and Television University, 4, pp. 28-29, 2012.

[22] Ma Deqing, Discussion about Undergraduate Teaching Assessment Characteristics Beijing Education (Higher Education Edition), 2, pp. 50, 2014. 